\title{
Uitvoering van interventieonderzoek in de bedrijfsgezondheidszorg Wat gaat goed, wat kan beter?
}

\author{
I.A. Steenstra • A.J. van der Beek • M.H. W. Frings- \\ Dresen • A. Burdorf • P.M. Bongers • W. van Mechelen
}

\begin{abstract}
Samenvatting Onderzoek in de bedrijfsgezondheidszorg is een zaak van vele partijen. Om tot succesvol onderzoek te komen zijn onderzoekers in de bedrijfsgezondheidszorg bijeengekomen om succes- en faalfactoren voor onderzoek in kaart te brengen. De bereidheid voor deelname aan onderzoek in de bedrijfsgezondheidszorg is groot, maar er dient voldaan te worden aan een aantal randvoorwaarden. De belangrijkste randvoorwaarden zijn: aansluiten bij onderzoeksvragen uit de praktijk en bij procedures in de praktijk om extra werkdruk te voorkomen, het aantal onderzoekshandelingen voor de bedrijfsarts en ondersteunend personeel te beperken, tegemoet te komen aan wensen van bedrijfsartsen, ondersteunend personeel en werkgevers, en zorg te dragen voor
\end{abstract}

I.A. Steenstra $(\square)$

PersonaliaDr. Ivan A. Steenstra was ten tijde van het onderzoek werkzaam bij de Afdeling Sociale Geneeskunde en bij het Instituut voor Extramuraal Geneeskundig Onderzoek, VU medisch centrum, en Body@Work, Onderzoekscentrum Bewegen, Arbeid en Gezondheid, TNO VUmc en is thans werkzaam bij het Coronel Instituut voor Arbeid, Milieu en Gezondheid, Academisch Medisch Centrum/Universiteit van Amsterdam (Klinische Methoden \& Public Health/ Onderzoeksinstituut AmCOGG). Prof. dr. Monique H. W. Frings-Dresen werkt bij Coronel Instituut voor Arbeid, Milieu en Gezondheid, Academisch Medisch Centrum/Universiteit van Amsterdam (Klinische Methoden \& Public Health/ Onderzoeksinstituut AmCOGG).Dr. Allard J. van der Beek, prof. dr. ir. Paulien M. Bongers en prof. dr. Willem van Mechelen werken op de Afdeling Sociale Geneeskunde en bij het Instituut voor Extramuraal Geneeskundig Onderzoek, VU medisch centrum, en Body@Work, Onderzoekscentrum Bewegen, Arbeid en Gezondheid, TNO VUmc; en prof. dr. ir. Paulien M. Bongers is tevens werkzaam bij TNO Kwaliteit van Leven Hoofddorp.Dr. Lex Burdorf werkt bij het Instituut Maatschappelijke Gezondheidszorg, Erasmus Universiteit Rotterdam.CorrespondentieadresDr. I.A. Steenstra, Coronel Instituut, AMC/UvA, Postbus 22660, 1100 DD Amsterdam.Email: i.a.steenstra@amc.uva.nl. voldoende financiering van extra handelingen en interventies binnen het onderzoek. Naar aanleiding van de bijeenkomst en naar aanleiding van vergelijkbare ervaringen bij onderzoek binnen de huisartsgeneeskunde is een checklist voor werving van bedrijfsartsen voor deelname aan onderzoek opgesteld.

Keywords voorwaarden voor onderzoek . interventieonderzoek · evidence-based medicine . academisering $\cdot$ financiering

\section{Inleiding}

Het grootste deel van de gebruikte interventies in de bedrijfsgezondheidszorg en de verzekeringsgeneeskunde is nog niet bewezen effectief. Goed onderzoek om te komen tot interventies van bewezen waarde is dan ook onmisbaar. Over de praktische gang van zaken binnen wetenschappelijk onderzoek wordt echter hoogstzelden gepubliceerd. Slechts in de voorwoorden, discussies en dankwoorden van proefschriften kunt $u$ er wel eens iets over lezen.

Enige tijd geleden heeft een bijeenkomst van onderzoekers van het Erasmus Medisch Centrum Rotterdam, VU medisch centrum Amsterdam, Academisch Medisch Centrum/ Universiteit Amsterdam en TNO Kwaliteit van Leven plaatsgevonden. Tijdens deze bijeenkomst werd stilgestaan bij de praktische problemen die men tegenkomt bij het opzetten van onderzoek in de bedrijfsgezondheidszorg. Bij het opzetten van goed onderzoek hebben onderzoekers namelijk niet alleen rekening te houden met wetenschappelijke criteria, maar dienen zij ook rekening te houden met praktische zaken. Bedrijfsgeneeskundig onderzoek kan immers niet plaatsvinden zonder deelname van de bedrijfsgezondheidszorg, bedrijven en werknemers. 
In dit artikel doen we verslag van de uitkomsten van deze bijeenkomst waarbij een onderverdeling is gemaakt naar deze drie groepen sleutelfiguren. In het verleden zijn vergelijkbare problemen en oplossingen al geschetst voor onderzoek in de huisartsgeneeskunde1 naar aanleiding van de NHG-wetenschapsdag 2001. Wij hebben geen literatuur kunnen vinden over dit onderwerp binnen de bedrijfsgezondheidszorg.

\section{Methode}

Tijdens de bijeenkomst werd door een aantal vertegenwoordigers van de verschillende onderzoeksgroepen een presentatie gegeven over het interventieonderzoek in de bedrijfsgezondheidszorg binnen het eigen instituut. Deze presentaties werden gevolgd door een plenaire discussie. Om tot een juiste samenvatting van de middag te komen heeft een vertegenwoordiger van ieder instituut (resp. A. Burdorf, M. Frings-Dresen, P. Bongers, I. Steenstra) een samenvatting geschreven van de bevindingen binnen het eigen instituut en de bevindingen van de bijeenkomst. Deze vier samenvattingen zijn kort samengevat in dit artikel, waarbij de vraag: 'wat kan beter?' centraal stond. Kenmerkend voor het in dit artikel beschreven onderzoek is dat het gerandomiseerde, gecontroleerde interventieonderzoeken zijn met ziekteverzuim als belangrijkste uitkomstmaat. In dit type onderzoek komen vrijwel alle praktische problemen binnen onderzoek aan bod. De geschetste problemen zijn dan ook vaak te generaliseren naar andere typen onderzoek in de bedrijfsgezondheidszorg.

\section{Wat kan beter?}

\section{Bedrijfsgezondheidszorg}

Al het onderzoek dat door de genoemde instituten op het terrein van arbeid en gezondheid wordt uitgevoerd, vindt plaats in samenwerking met de bedrijfsgezondheidszorg (i.e. bedrijfsartsen, bedrijfsverpleegkundigen, teamsecretaresses, ergonomen, arboadviseurs, aanbieders van rugscholingsprogramma's en fysiotherapeuten). Uitgangspunt bij alle interventieonderzoeken is dat het onderzoek aansluit bij de dagelijkse werkzaamheden van professionals in de bedrijfsgezondheidszorg.

Over het algemeen is de bereidheid om te participeren in onderzoek bij arboprofessionals groot. Desondanks stuit de uiteindelijke uitvoering van interventieonderzoek op hindernissen. Voor bedrijfsartsen en fysiotherapeuten wordt deelname belemmerd door de ervaren hoge werkdruk. De onderzoekers trachten daarom vaak extra werkdruk te verminderen door taken van een arboprofessional binnen het onderzoek tot een minimum te beperken. Zo wordt in sommige onderzoeken de werknemer door de onderzoekers zelf voorgelicht over het onderzoek. Ook worden de procedures voor de bedrijfsarts zo eenvoudig mogelijk gehouden, zodat deze de bedrijfsarts weinig extra werk opleveren. Vaak kunnen accreditatiepunten worden verkregen als beloning voor de geleverde inspanningen. Arbodiensten zouden onderzoek kunnen faciliteren door bijvoorbeeld extra ondersteuning aan deelnemende bedrijfsartsen aan te bieden.

Binnen de bedrijfsgezondheidszorg bestaat veelal onbekendheid met gerandomiseerd onderzoek, hoewel deze vorm van onderzoek binnen de geneeskunde en de gezondheidszorg veelvuldig wordt uitgevoerd. De huidige huiver in de bedrijfsgeneeskunde voor gerandomiseerde onderzoeken vormt een barrière voor de wetenschappelijke onderbouwing van het vakgebied.

Het verlenen van medewerking aan onderzoek op het gebied van behandeling van klachten door de behandelaars c.q. reïntegratiebedrijven vergt veel afstemming en voorbereidingstijd. Intensieve samenwerking met één of enkele vestigingen van één arbodienst en samenwerking met een beperkt aantal marktpartijen vergemakkelijkt de afstemming tussen alle partijen.

\section{Bedrijven}

Medewerking van bedrijven is onmisbaar voor onderzoek op het gebied van de bedrijfsgezondheidszorg. De kosten van interventies moeten naar mening van subsidiegevers meestal gedragen worden door de deelnemende bedrijven. In sommige onderzoeken wordt een tijdsinvestering gevraagd van de werkgever. De ervaring leert dat bedrijven sneller meewerken aan onderzoek, als er voor hen geen kosten aan verbonden zijn. Externe financiering van de interventies is in enkele gevallen dan ook een voorwaarde gebleken voor het niet doen mislukken van het onderzoek. Deze aanvullende financiering kwam slechts moeizaam tot stand en leidde altijd tot vertraging van het onderzoek. De bereidheid van bedrijven tot medewerking wordt vergroot door het uitvoeren van een kosteneffectiviteitsanalyse voor de onderzochte interventies. Als rekrutering via arbodiensten lastig is, kunnen deelnemers voor onderzoek via de brancheorganisaties worden gerekruteerd. De medewerking van brancheorganisatie en aangesloten bedrijven is dan van groot belang. Loting in experimentele (interventie) dan wel in controlegroep wordt door bedrijven vaak als een probleem gezien. Ondanks het feit dat de controlegroep de gebruikelijke zorg ontvangt, wordt dit ten onrechte vaak gezien als het onthouden van adequate zorg aan de controlegroep. 
Tabel Checklist bij werving van bedrijfsartsen voor deelname aan onderzoek

Categorie* 1

Opzet van het onderzoek

- formuleer relevante vraagstelling voor de bedrijfsgezondheidszorg in het algemeen

- formuleer een vraagstelling die aansluit bij de belangstelling van de bedrijfsarts, die interessant, herkenbaar, noodzakelijk is

- ga op zoek naar geïnteresseerde bedrijfsartsen (die niet onderzoeksmoe zijn)

- betrek de bedrijfsarts in een zo vroeg mogelijk stadium bij het project

- laat alom gerespecteerde bedrijfsartsen het project bij bedrijfsartsen introduceren

- organiseer voorafgaande aan het onderzoek een aantrekkelijke scholings- en/of

informatiebijeenkomst voor alle betrokkenen

- probeer niet alleen scholing maar ook onderzoekswerk geaccrediteerd te krijgen

Ondersteuning van bedrijfsarts en ondersteunend personeel

- neem zoveel mogelijk onderzoeks- of praktijkwerk uit handen van de bedrijfsarts

en assistent (administratie, voorlichting, screening)

- beperk de onderzoeksactiviteiten van bedrijfsarts en ondersteunend personeel

(tot noodzakelijke of leuke taken)

- maak gebruik van 'reminders' (herinneringsobjecten of geautomatiseerde meldingen)

op de arbodienst

- sluit aan bij de praktijk, betrek de wensen van de arts en ondersteunend personeel,

handhaaf de professionele autonomie van de betrokkenen, zorg voor weinig overlast

- werk met vaste contactpersonen zowel binnen het onderzoek als binnen de arbodienst

- bespreek en informeer geregeld naar mogelijke knelpunten

Informatieverstrekking

- geef voorafgaand, tijdens en direct na de onderzoeksperiode aantrekkelijk verpakte informatie

over het onderzoek en feedback over het functioneren

- geef informatie in de vorm van nieuwsbrieven, bezoeken, scholingsbijeenkomsten, minisymposia

- houd informatie beperkt en doelgericht

Beloning

- zorg voor een reële vergoeding voor de activiteiten die vanuit het onderzoek verricht moeten

worden, neem deze kosten op in de begroting van het onderzoek

- neem de betrokken bedrijfsartsen en assistenten op in dankwoord en 'acknowledgements'

- toon waardering door middel van attenties, bezoek aan de praktijk, telefoontjes

De rol van het ondersteunend personeel/aanspreekpunt op de arbodienst

- inventariseer ook de motivatie van het ondersteunend personeel

- betrek ondersteunend personeel nadrukkelijk in het onderzoek, verwerk praktische tips in je procedure

- zorg voor een passende beloning voor de assistentes

Speciale aandachtspunten binnen de bedrijfsgezondheidszorg

- informeer het management en vraag commitment

- werk binnen één arbodienst of vestiging om de communicatie te verbeteren en het

commitment te vergroten

- informeer bedrijven en vraag hun commitment

- werk eventueel samen met brancheorganisaties van werkgevers

- voer een kosteneffectiviteitsanalyse uit binnen het onderzoek

${ }^{*}$ Categorie $1=$ naar Huibers et al.,1 2 = uit bijeenkomst onderzoekers bedrijfsgezondheidszorg.

\section{Werknemers}

Deelname aan het onderzoek door werknemers wordt soms bemoeilijkt door een beperkte beheersing van de Nederlandse taal door allochtone en laaggeschoolde werknemers. Bovendien worden verzuimende werknemers in sommige gevallen pas laat op het spreekuur gezien, zodat de benodigde aantallen werknemers op basis van de vooraf opgestelde inclusiecriteria niet worden gehaald. Bij de opzet van onderzoek dient hiermee rekening te worden gehouden. 
Positieve ervaringen

Op het moment dat een onderzoek eenmaal loopt, is een aantal positieve punten te noemen. De onderzochte interventies worden positief ontvangen en uitgevoerd door de verschillende professionals. De trainingen in de verschillende protocollen leiden tot een verhoogde deskundigheid die ook gebruikt kan worden bij andere klachten. Accreditatie die men heeft verkregen, blijkt in de praktijk zeer te worden gewaardeerd.

De instroom van deelnemers via arbodiensten in een gerandomiseerd experiment wordt bevorderd door de aanwezigheid van een reïntegratiemedewerker of bedrijfsverpleegkundige met duidelijke taken bij het identificeren en organiseren van de instroom van patiënten.

\section{Conclusies}

Samenvattend lijken er nog al wat haken en ogen te zitten aan onderzoek in de bedrijfsgezondheidszorg naar de effectiviteit van interventies gericht op werkhervatting. De genoemde problemen zijn wellicht illustratief voor het doen van onderzoek in een veld waar het verrichten van onderzoek nog geen routine is en waar de waan van alledag de agenda bepaalt. In deze pioniersfase van interventieonderzoek in de bedrijfsgezondheidszorg is door de vier instituten al veel kennis en ervaring opgedaan om onderzoek nu en in de toekomst succesvol te verrichten.

Een belangrijke conclusie is dat het van groot belang is, dat dit type interventieonderzoek aansluit op de arbopraktijk. Door reeds in de onderzoeksfase rekening te houden met de praktische invoering van de interventies wordt de implementatie van de resultaten in het veld vereenvoudigd. De bijdrage van verschillende praktijkmensen in een vroeg stadium is hierbij onmisbaar. Al het onderzoek moet uiteindelijk leiden tot een goede onderbouwing van (para)medisch handelen in de bedrijfsgezondheidszorg.

Bij vergelijking van de resultaten van de onderzoekersbijeenkomst en de NHG-wetenschapsdag blijken in beide settings vrijwel dezelfde problemen te bestaan en zijn ook de oplossingen vrijwel identiek. Voor een overzicht van de literatuur verwijzen wij dan ook graag naar het artikel van Huibers et al. ${ }^{1} \mathrm{Zij}$ hebben op basis van hun bevindingen een checklist gemaakt die onderzoekers kan helpen bij het succesvol werven van artsen voor onderzoek. In de tabel vindt $\mathrm{u}$ een aangepaste versie van deze lijst. Bedrijfsartsen zijn bijvoorbeeld (nog) niet onderzoeksmoe, de ervaringen in onderzoek bij huisartsen leert ons hier voor op te passen. Een aantal andere in de lijst genoemde punten is niet tijdens de bijeenkomst aan de orde gekomen, maar de beschreven acties zijn binnen het onderzoek van de betrokken instituten wel toegepast.

Onderzoeksresultaten van de verschillende onderzoeken zullen de komende jaren bekend worden. U kunt verder informatie over (de vorderingen binnen) de onderzoeken vinden via:

http://www.amc.nl/index.cfm?pid = 376,

www.eur.nl/fgg/mgz/,

http://www.tno.nl/kwaliteit_van_leven/markten/ arbeid/,

www.emgo.nl, en www.bodyatwork.nl.

\section{Literatuur}

Huibers M, Windt DAWM van der, Boeke AJP. De deelname van huisartsen aan wetenschappelijk onderzoek: problemen en oplossingen. Huisarts Wet 2002; 45: 454-458. 